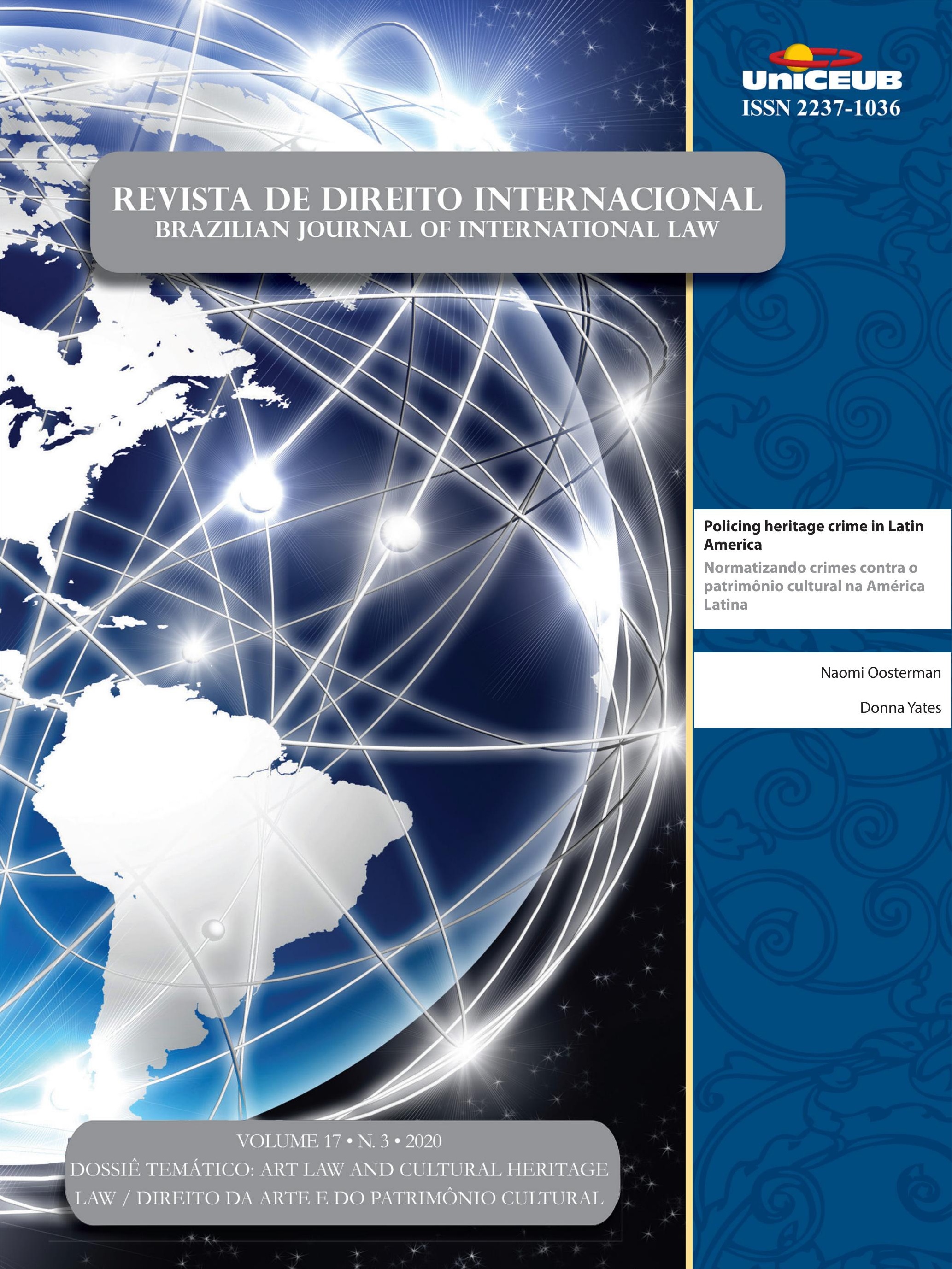




\section{Sumário}

EDITORIAL .20

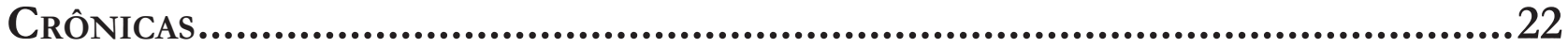

O COSTUME INTERNACIONAL COMO REFORÇO DA OBJEÇÃO BRASILEIRA À CLÁUSULA DO TRATAMENTO JUSTO E EQUITATIVO .24

Leonardo Vieira Arruda Achtschin

O PROCESSO LEGISLATIVO COMO GARANTIA PARA A OBTENÇÃo DO CONSENTIMENTO PRÉVIO DAS COMUnidades quilombolas de AlCÂNTARa

Gabriel de Oliveira Borba

Dossiê temático: Art Law and Cultural Heritage law / Direito da Arte e do Patrimônio cultural - Panorama Geral

Peoples' heritage or States' heritage? sovereignty in the UNESCO mechanism for THE SAFEGUARDING OF INTANGIBLE CULTURAL HERITAGE.

Aliki Gkana

The IMPACT OF THE UNESCO AND UNIDROIT CONVENTIONS AND THE EU DIRECTIVES ON THE INTERNATIONAL ART MARKET: AN ANALYSIS FIFTY YEARS AFTER THE INTRODUCTION OF THE OBLIGATION TO RETURN STOLEN OR ILLEGALLY EXPORTED CULTURAL GOODS 61

Geo Magri

Três pautas em destaque na agenda de diversidade Cultural da Unesco: Ambiente digiTAL, TRATAMENTO PREFERENCIAL E PARTICIPAÇÃO DA SOCIEDADE CIVIL............................76

Danilo Júnior de Oliveira, Maria Carolina Vasconcelos Oliveira e Ana Paula do Val

A 100 YEARS INSTITUTIONALIZED CULTURAL HERITAGE PROTECTION: FROM THE INSTITUTIONALIZED INTERNATIONAL COOPÉRATION INTELLECTUELLE TO THE HUMAN RIGHT TO CULTURAL HERITAGE

Lando Kirchmair 


\section{Aspectos Metodológicos do Direito da Arte e do Patrimônio}

Cultural

A proteção do PATrimônio CULTURAL EM NOVAS PERSPECTIVAS: ESTUdo COMPARAdo ENTRE A Kulturgutschutzgesetz e a Holocaust Expropriated Art Recovery Act of 2016.....111 Ardyllis Alves Soares

ArT-RELATED DispUTES AND ADR METHODS 127 Maria Beatrice Deli e Veronica Proietti

Due Diligence in Art Law and Cultural Heritage Law 150 Lisiane Feiten Wingert Ody

The Reception of Droit de Suite in International Law: Diagnosis and Remedy .... 170 Mickael R. Viglino

Direito da Arte e do Patrimônio Cultural: do Regional ao Local ....... 188

Câmara Cascudo e o legal Design - A Visualidade do Direito entre Provincianismo e GlobalizaÇão 190 Marcilio Toscano Franca Filho

A política da União Europeia no turismo: O turismo cultural e a sustentabilidade do PATRIMONNIO INDUSTRIAL PARA INTEGRAÇÃO DO BLOCO EUROPEU

Maraluce Maria Custódio e Fernando Barotti dos Santos

Diálogo entre la Corte Interamericana de Derechos Humanos y el Tribunal Europeo de Derechos Humanos en torno al Derecho humano a la identidad cultural..223 Juan Jorge Faundes

Digital ART AND THE BELT AND ROAD INITIATIVE: CHALLENGES AND OPPORTUNITIES 257 Dan Wei e Ângelo Rafael

Policing heritage crime in Latin America. .275 Naomi Oosterman e Donna Yates 
The principles of Cultural Heritage Law based on the Polish Law as an example.292 Małgorzata Joanna Węgrzak e Kamil Zeidler

Heritage Protection in INTERNATIONAL LAw AND NATIONAL LAW: INSIGHTS INTO THE CASE OF VIETNAM

Yen Thi Hong Nguyen e Dung Phuong Nguyen

THE APPROPRIATION OF THE CARIOCA INTANGIBLE CULTURAL HERITAGE BY AN ENTREPRENEURIAL LOGIC

Mário Ferreira de Pragmácio Telles

A Propósito del CARÁcter UNIVERSAL DEL aCCESO A LA CULTURA EN INTERNET: UN ANÁlisis DESDE EL PRISMA INTERNACIONAL Y LA EXPERIENCIA DEL ORDENAMIENTO JURÍDICO CUBANO 344 Janny Carrasco Medina

Direito Humanitário e Arte

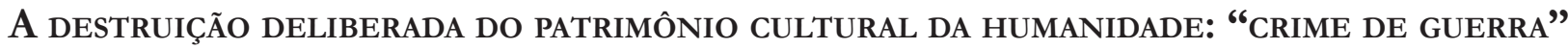
OU "CRIME CONTRA A HUMANIDADE"? Juliette Robichez

Protection OF CULTURAL PROPERTY UNDER INTERNATIONAL HUMANITARIAN LAW: EMERGING TRENDS

Niteesh Kumar Upadhyay e Mahak Rathee

Direito do Mar/Marítimo e Arte.

The underwater Cultural heritage Regime: SOME PROBlems AND POSSible SOlutions. 412 Elina Moustaira

El ROL DEL DERECHO EN LA CONSTRUCCIÓN DEL PATRIMONIO CULTURAL SUBACUÁTICO: APRECiaciones a partirdel estudio del CASo de la Corbeta Inglesa SwifT en Argentina .. 424 Norma Elizabeth Levrand e Nadia Bressan Bernhardt 
INDIGENOUS REFUGEES AND CULTURAL EROSION: POSSIBILITIES AND LIMITS OF INTERNATIONAL REFUGEE AND INDIGENOUS PEOPLES LAW IN THE PROTECTION OF INDIGENOUS CULTURAL EXPRESSIONS RELATED TO TRADITIONAL LAND AND NATIVE LANGUAGE. .440 Rickson Rios Figueira

O RETRATO DE EDMOND BELAMY E A INTERFACE ENTRE ARTE E INTELIGENCIA ARTIFICIAL: POR UMA NOVA DEFINIÇÃo DE AUTORIA E DIREITOS DE PROPRIEDADE INTELECTUAL

Marla Meneses do Amaral Leite Mangiolardo, Patrícia Silva de Almeida e Jonathan Barros Vita

Argumentative aspects of Declaration on the Importance and Value of Universal Museums (2002) 479

Agnieszka Plata

A DestinaÇão dos bens CUlturais EM PROCESSOS PENAIS: A ARTE COMO REPARAÇÃo COLETIVA 488

Inês Virgínia Prado Soares e Otavio Venturini

A Justiça de Pieter Bruegel: direito, violência e a venda nos (nossos) olhos. .501 Rafael Lazzarotto Simioni e Cícero Krupp

Artigos Sobre outros temas

DEVERES INTERNACIONAIS E OBRIGAÇÕES SOCIOAMBIENTAIS PARA EMPRESAS MULTI E TRANSNACIONAIS

Luísa Cortat Simonetti Gonçalves e Adriano Sant'Ana Pedra

Maternidade por substituição: perspectivas da ConferênCia da Haia e suas potenciais INFLUÊNCIAS NO REGRAMENTO BRASILEIRO

Tatiana de A. F. R. Cardoso Squeff e Fernanda Rezende Martins

EL (LARGO) CAMINO DE RECONOCIMIENTO Y EJECUCIÓN DE LAUDOS ARBITRALES DE INVERSIÓN

Thiago Paluma, Ivette Esis e Gabriel Briceño 
A INTERPRETAÇÃo EVOLUTIVA DA CONVENÇÃo AMERICANA SOBRE DiREITOS HUMANOS: UMA REVISÃO DOCUMENTAL DO PERÍODO 1988-2018

Breno Baía Magalhães

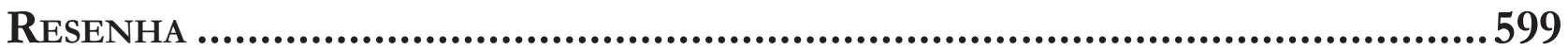

Autonomous Weapons Systems and InTERnATIONAL LAw: A STUDY ON HUMAN-MACHINE INTERACTIONS IN ETHICALLY AND LEGALLY SENSITIVE DOMAINS

Aziz Tuffi Saliba e Lutiana Valadares Fernandes Barbosa 


\title{
Policing heritage crime in Latin America*
}

\section{Normatizando crimes contra o patrimônio cultural na América Latina}

\author{
Naomi Oosterman** \\ Donna Yates***
}

* Recebido em 11/08/2020

Aprovado em 02/03/2021

** Lecturer at the Department of Arts and Culture Studies of the Erasmus University Rotterdam. She is furthermore an affiliated researcher in the "Heritage under Threat" branch of the Centre for Global Heritage and Development. Late 2018, Oosterman finished her doctoral dissertation focusing on the criminal dynamics of art crime in the European Union. In her research, she focuses on the criminogenic aspects of the art world, the nature of art and heritage crime, and the policing of public art collections. Her research combines theories from the fields of cultural criminology, sociology, and cultural studies.

E-mail: oosterman@eshcc.eur.nl

*** Associate Professor in Criminal Law and Criminology at Maastricht University. Prior to this, she was a Senior Lecturer in Antiquities Trafficking and Art Crime at the Scottish Centre for Crime and Justice Research at the University of Glasgow. She is a founding member of the Trafficking Culture research consortium (traffickingculture.org) and she is the Principal Investigator in the European Research Councilfunded project "Trafficking Transformations: Objects as Agents in Criminal Networks" which looks at the role that collectable objects, such as antiquities, play in the illicit networks that they are part of. Yates has published widely in the field of art and antiquities crime.

E-mail: d.yates@maastrichtuniversity.nl

\section{Abstract}

Artefacts from Latin America are popular on international art markets, however their supply is closely linked to heritage crimes such as looting, illegal excavations, and theft. This results in a wide and ongoing circulation of artefacts with illicit origins, despite Latin American states claiming ownership. Regulation and policy responses are continuously developed to address the opaque market structures and criminal networks facilitating this illicit trade in Latin America, with policing as the first line of defence against heritage crimes. Despite increasing research into the illicit trafficking of cultural artefacts in the region, specific strategies and interregional cooperation within heritage crime policing in Latin America has rarely been discussed. Therefore, we examine the policing, prevention, and legislation tactics in twelve Latin American countries as a state-by-state survey, and provide an overview of the current regional and international collaborations concerning the policing of heritage crime. We conclude that there is significant collaboration between Latin American countries, but that improvements could be made regarding the number of dedicated specialists within police and government agencies. This lack of economic resources and specialists within relevant agencies has been recorded in locations beyond Latin America, and we assert that this is the primary weakness in regional and global efforts to police heritage crimes.

Keywords: Policing. Heritage crime. Latin America. Legislation. Cultural objects.

\section{Resumo}

Artefatos da América Latina são populares nos mercados internacionais de arte, no entanto, seu suprimento está intimamente ligado a crimes de patrimônio, como pilhagem, escavações ilegais e furto. Isso resulta em uma circulação ampla e contínua de artefatos com origens ilícitas, apesar dos estados latino-americanos reivindicarem a propriedade. As respostas regulatórias e políticas são desenvolvidas continuamente para abordar as estruturas opacas do mercado e as redes criminosas que facilitam esse comércio ilícito na América Latina, com o policiamento como a primeira linha de defesa contra os crimes patrimoniais. Apesar do aumento da pesquisa sobre o tráfico ilícito de artefatos culturais na região, estratégias específicas 
e cooperação inter-regional dentro do policiamento do crime patrimonial na América Latina raramente foram discutidas. Portanto, examinamos as táticas de policiamento, prevenção e legislação em doze países latinoamericanos como uma pesquisa estado por estado e fornecemos uma visão geral das atuais colaborações regionais e internacionais relativas ao policiamento de crimes patrimoniais. Concluímos que existe uma colaboração significativa entre os países latino-americanos, mas que poderiam ser feitas melhorias no que diz respeito ao número de especialistas dedicados na polícia e nas agências governamentais. Essa falta de recursos econômicos e especialistas dentro de agências relevantes foi registrada em locais fora da América Latina, e afirmamos que esta é a principal fraqueza nos esforços regionais e globais para policiar crimes patrimoniais.

Palavras-chave: onde tem fiscalização, colocar normatização.

\section{Introduction}

Since approximately the 1960s, Latin American artefacts $^{1}$ have been popular on the international art market ${ }^{2}$. Specialised dealerships and targeted auction sales were developed to meet consumer demand for these objects. However, market supply of this was, and is, problematic. Most Latin American countries claim blanket ownership of all heritage items within their territory, prohibiting their extraction, transfer, and export for market purposes. Without a licit supply stream, dealers and consumers of especially non-contemporary Latin American art turned to material that is looted or stolen from its country of origin, smuggled to a market country, and sold via a series of opaque market practices that serve to shield illicit origins ${ }^{3}$. The resulting ancient

\footnotetext{
In this article, we focus on ancient and historic objects that exist as a protected class under the law of the country in question. The exact definition of this is different for each country, but the objects in question mostly relate to the pre-Conquest, Colonial, or early Republican periods. We will use the terms "artefact" or "cultural object" to refer to these pieces, and the term "heritage crime" to refer to violations of the national laws related to those objects.

2 Yates, Donna. Illicit cultural property from Latin America: Looting, trafficking, and sale. In: Desmarais, France. (Ed.). Countering illicit traffic in cultural goods: The global challenge of protecting the world's heritage. Paris: ICOM, 2015. p. 33-46.

3 Mackenzie, Simon; Brodie, Neil; Yates, Donna. Trafficking Culture: New Directions in Researching the Global Market in Illicit Antiquities. New York: Routledge, 2020.
}

and historic Latin American art market is saturated with over six decades worth of illicit material, the identification and recovery of which remains an ongoing challenge. Recent seizures of looted and stolen Latin American cultural objects evidence both a strong market demand and the continued existence of criminal networks who act as suppliers (see discussion of Operations Athena II and Pandora IV below). These networks start with the initial displacement of cultural objects from Latin American heritage sites, posing a policing challenge for the "source" countries in the region, as well as the intermediary countries that these objects transit through.

At their earliest stages, trafficking routes for these objects are transnational. Although investigation of the intraregional illicit trade in cultural objects within Latin America is nearly absent within academic literature, it is a structural reality that requires police response. For example, on 7 September 2015, Argentinian newspaper Clarín reported that Argentinian police orchestrated two operations at the border of Gualeguaychú between Argentina and Uruguay ${ }^{4}$. In these operations, the Administración Federal de Ingresos Públicos through the Argentinian border control, confiscated several cultural artefacts. The objects were destined for Montevideo through which some objects were likely destined for Europe. In 2008, the Brazilian minister for culture Gilberto Gil, after recovering three stolen works of art from the Museu de Arte de Sao Paulo including works by Candido Portinari and Pablo Picasso, argued that the theft was most likely orchestrated by "international gangs" and commissioned by thieves from "overseas" territories. At the same time, recent seizures and returns indicate that Brazil may be one of the primary intermediate marketplaces for stolen Colonial-period art from Andean countries such as Bolivia and Perú ${ }^{5}$.

Local policing efforts represent the first and, perhaps, the most important line of defence against this type of heritage exploitation. Local police are tasked with both the prevention and investigation of heritage crimes, and particularly with combatting trafficking. Considering

\footnotetext{
CLARÍN. Los detienen en un control de rutina cuando querian contrabandear obras de arte hacia Uruguay. September 7, 2015. Available at: https://www.clarin.com/policiales/gualeguaychu-caen-queriancontrabandear-uruguay_0_r1otP7tP7e.html. Accessed on: March 2, 2021.

5 Agencia EFE. Bolivia recovers stolen art thanks to belp from U.S. couple. April 9, 2015. Available at: https://www.efe.com/efe/english/life/bolivia-recovers-stolen-art-thanks-to-help-from-u-s-couple/50000263-2582190. Accessed on: March 2, 2021.
} 
that this type of crime is frequently transnational, there has been increasing emphasis in recent years placed on international and regional collaborations for countering illicit trafficking in Latin America, as well as an increase in the development of policy measures designed to prevent these objects from displacement.

As previously mentioned, very little is presented in the academic literature about the intraregional illicit trade in Latin America, and the first line of defence against this trade: the police. Academic studies have primarily focused on law enforcement efforts of heritage crimes in general $^{6}$ and on trafficking specifically ${ }^{7}$. The nature and scope of heritage crime in Latin America has been documented through extensive research ${ }^{8}$, however the

\footnotetext{
Oosterman, Naomi. Regional overviews of the policing of art crime in the European Union. In: Hufnagel, Saskia; Chappell, Duncan. (Eds.). The Palgrave Handbook on Art Crime. London: Palgrave Macmillan, 2019; Polk, Kenneth; Chappell, Duncan. Policing and prosecution of heritage crime: revisiting the Cordata-just how organised is the international traffic in cultural heritage?. In: Mitsilegas, Valsamis; Hufnagel, Saskia; Moiseienko, Anton. (Eds.). Research Handbook on Transnational Crime. London: Edward Elgar Publishing, 2019; Kerr, John. The securitization and policing of art theft: The case of London. London: Routledge, 2016; BLOCK, Ludo. European police cooperation on art crime: Comparative overview. Journal of Art Crime, v. 5, n. 1, p. 13-26. 2011.

Mackenzie, Simon; Brodie, Neil; Yates, Donna. Trafficking Culture: New Directions in Researching the Global Market in Illicit Antiquities. New York: Routledge, 2020; Brodie, Neil; Sabrine, Isber. The illegal excavation and trade of Syrian cultural objects: a view from the ground. Journal of Field Archaeology, v. 43, n. 1, p. 74-84. 2018; Yates, Donna. The global traffic in looted cultural objects. In Rafter, Nicole; Carrabine, Eamonn. (Eds.). The Oxford Encyclopedia of Crime, Media, and Popular Culture. Oxford: Oxford University Press, 2016; Yates, Donna; Mackenzie, Simon; Smith, Emiline. The cultural capitalists: Notes on the ongoing reconfiguration of trafficking culture in Asia. Crime, Media, Culture, v. 13, n. 2, p. 245-254. 2017; Hardy, Samuel Andrew. Illicit trafficking, provenance research and due diligence: The state of the art. Paris: United Nations Educational, Scientific and Cultural Organization (UNESCO), 2016; Mackenzie, Simon; Davis, Tess. Temple looting in Cambodia. Anatomy of a statue trafficking network. British Journal of Criminology, v. 54, n. 5, p. 722-740. 2014; Rodríguez Temiño, Ignacio; Roma ValdÉs, Antonio. Fighting against the archaeological looting and the illicit trade of antiquities in Spain. International Journal of Cultural Property, v. 22, n. 1, p. 111130. 2015; Manacorda, Stefano; Chappell, Duncan. (Eds.). Crime in the art and antiquities world: Illegal trafficking in cultural property. New York: Springer Science \& Business Media, 2011.

8 See Yates, Donna. Displacement, Deforestation, and Drugs: Antiquities Trafficking and the Narcotics Support Economies of Guatemala. In: Kila, Joris; Balcells, Marc. (Eds.). Cultural Property Crime. An overview and analysis contemporary perspectives and trends. Leiden: Brill, 2014. p. 21-36; Yates, Donna. Church theft, insecurity, and community justice: The reality of source-end regulation of the market for illicit Bolivian cultural objects. European Journal on Criminal Policy and Research, v. 20, n. 4, p. 445-457. 2014; Yates, Donna. Illicit cultural property from Latin America: Looting, trafficking, and sale.
}

policing of these crimes within the region itself is rarely discussed. Additionally, few academic studies have focused on describing legislation and policy efforts in the Latin American region concerning the trafficking of cultural goods. Whereas general studies concerning trafficking have taken a global approach, studies on heritage crime policing have mostly focused on European and Australian contexts. Our understanding of heritage crime therefore lacks systematic and descriptive information about "source end" policing generally, policing in Latin America specifically, and local efforts concerning legislation and policy to counteract trafficking.

This article therefore serves as a first step toward widening the discourse on heritage crime policing by examining the existing policing, policy, and legal efforts employed in Latin America. It takes a unique approach in presenting a first systematic overview of the practices of twelve Latin American countries concerning the policing of heritage crime, as well as the interregional and international cooperation efforts that Latin American countries participate in towards the prevention and investigation of cultural heritage crimes. Rather than providing a discussion of legislation, we collected data from actors who are 'on the ground' by contacting those people in relevant positions in, for example, the national police forces, cultural ministries, and museums. By taking this approach, we are able to contextualise existing legislation in the everyday practice of those actors involved in the enforcement of heritage crime. With this article, we aim to concretise and specify the current legal, policy, and policing efforts in Latin America, as well as the discussion of the prevention of intraregional illicit trade. The results presented in this article serve as an invitation for further research into source country trafficking in Latin America, and the further investigation of the 'on the ground' daily routines and

In: Desmarais, France. (Ed.). Countering illicit traffic in cultural goods: The global challenge of protecting the world's heritage. Paris: ICOM, 2015. p. 33-46; Yates, Donna. Reality and practicality: Challenges to effective cultural property policy on the ground in Latin America. International Journal of Cultural Property, v. 22, n. 2-3, p. 337-356. 2015; Yates, Donna. The global traffic in looted cultural objects. In Rafter, Nicole; Carrabine, Eamonn. (Eds.). The Oxford Encyclopedia of Crime, Media, and Popular Culture. Oxford: Oxford University Press, 2016; Yates, Donna. Cultural heritage offences in Latin America: Textile traffickers, mummy mailers, silver smugglers, and virgin vandals. In: Hufnagel, Saskia; Chappell, Duncan. (Eds.). The Palgrave Handbook on Art Crime. London: Routledge, 2019. p. 483-501; Yates, Donna; Tremain, Cara Grace. (Eds.). The Market for Mesoamerica: Reflections on the Sale of Pre-Columbian Antiquities. Gainsville: University Press of Florida, 2019. 
decision-making processes of those involved in the enforcement of heritage crime.

\section{Interregional and international cooperation in Latin America}

In 2019, Operations Athena II and Pandora IV, which were collaborations between Interpol, Europol, the World Customs Organisation, and various national law enforcement agencies, were concluded. The result was the recovery of over 19,000 artefacts and cultural objects from 103 countries. Around 100 individuals were arrested, uncovering various organised criminal networks. After publication of the results of these operations in May 2020, Jürgen Stock, Secretary General of Interpol, stated that "The number of arrests and objects show the scale and global reach of the illicit trade in cultural artefacts, where every country with a rich heritage is a potential target". Due to the market demand for Latin American cultural objects, the involvement of several countries from Latin America in these operations is unsurprising.

In recent years, there has been an increase in cooperation between countries in Latin America, specifically focusing on enhanced intelligence sharing between states. La Comunidad de Policías de América (AMERIPOL) is an international policing organisation that focuses on the coordination and intelligence sharing between law enforcement agencies in the Americas. AMERIPOL, which is headquartered in Bogotá, was founded in 2007 to promote and strengthen police cooperation, provide training, and organise the exchange of police intelligence between member states. AMERIPOL has a coordinating role in criminal investigation and judicial actions between law enforcement agencies and equivalent institutions in the Americas. Currently, AMERIPOL has 33 law enforcement members within the Americas and 26 observer organisations that are located internationally such as Interpol and Europol, but also the German Bundeskriminalamt, and Italian Carabinieri. AMERIPOL has a similar structure to Interpol, where every member state has a Unidad Ameripol (UNA) which functions similarly to the National Cen-

Europol. 101 arrested and 19,000 stolen artefacts recovered in international crackdown on art trafficking [press release]. May 6, 2020. Available at: https://www.europol.europa.eu/newsroom/news/101-arrestedand-19000-stolen-artefacts-recovered-in-international-crackdownart-trafficking. Accessed on: March 2, 2021. tral Bureau (NCB) of Interpol. The UNA is the primary communication vehicle for the exchange of intelligence from law enforcement agencies to AMERIPOL headquarters for further dissemination. AMERIPOL does not maintain a department or database specifically for heritage crimes. Nonetheless, many of the states surveyed for this article report that they actively use the AMERIPOL network to disseminate operations in the case of a crime against heritage.

One of these cooperation efforts that factors in heritage crime is El PACcTo (Europa Latinoamérica Programa de Asistencia contra el Crimen Transnacional Organizado), which is an international programme that focuses on enhancing and facilitating international cooperation against organised crime between the European Union and Latin American countries. Additionally, it aims to share best practices and provide and enhance technical assistance. The program is funded by the European Union and runs from 2017 to 2022. Unique to El PACcTo is that it focuses on the entire criminal justice system in the associated countries, meaning it concerns law enforcement agencies, justice systems, and penitentiary systems. In June 2020, 11 member countries ${ }^{10}$ participated in a webinar concerning illicit trafficking of cultural property in Latin America, discussing how to investigate and combat the organised crime associated with it. Besides representatives of Latin American countries, European law enforcement specialists from Spain (Grupo de Patrimonio Histórico) and Italy (Carabinieri per la Tutela del Patrimonio Culturale), as well as Interpol and UNIDROIT, were present. The recommendations of the webinar are six-fold ${ }^{11}: 1$ ) development of uniform regulations for the protection of cultural heritage, especially concerning the restitution of objects, 2) improvement of international judicial cooperation, 3) implementation of databases specifically concerning cultural property, 4) increase of formal and informal cooperation between countries, 5) increased use of specialist investigation techniques and 6) obligatory recording of items by those parties involved in the selling and buying of artworks. Many of the discussed law enforcement agencies in this article are active within El PAcCTO.

\footnotetext{
10 Argentina, Bolivia, Chile, Costa Rica, Ecuador, El Salvador, México, Panama, Paraguay, Perú, Uruguay.

11 El PACcTO. New cooperation tools to investigate trafficking in cultural property [press release]. June 23, 2020. Available at: https://www.elpaccto.eu/en/news/new-cooperation-tools-to-investigate-trafficking-in-cultural-property/. Accessed on: March 2, 2021.
} 


\section{Policy, policing, and legislation in Latin America}

In the following section, we will focus on policing, policy, and legislation concerning cultural heritage crimes in twelve countries in Latin America. The information presented was obtained from representatives within relevant national governments or specialised law enforcement agencies who were contacted under the aegis of the ERC-funded Trafficking Transformations project ${ }^{12}$. Representatives were asked the following questions, and were encouraged to expand upon them as they saw fit:

1. Who is tasked with investigation of heritage crimes? Is there a dedicated police unit or equivalent within another agency or within the relevant cultural ministry? or We know that there exists a dedicated police unit focused on heritage crimes, how is that unit managed and are there any updates about it that you can share?

2. What is the normal procedure when a heritage crime is reported? What agencies/ offices are notified within and beyond?

3. What kinds of inter-regional cooperation is participated in concerning the prevention of heritage crime?

4. What do you believe are the country's strengths and weaknesses regarding policing of heritage crime?

The data was collected between 1 April and 31 July 2020 and was supplemented by data collected from government and agency sources available online, including statements on official websites, recordings of presentations made by heritage officials, and some limited information contained in the popular media. Countries absent are those we were unable to obtain responses from within the time limit of this publication, and do not indicate a lack of heritage crime policing. The detail of the information provided relates to the extent of the information provided to us and is unrelated to levels of regulation or policing within the country. We

12 Grant agreement $n^{\circ}$ 804851. Ethical clearance for this research was provided by the Maastricht University ERCIC and the European Research Council Ethics Review Panel. All respondents are granted anonymity in accordance with our ethical guidelines. look forward to expanding this survey when additional information is received.

\subsection{Argentina}

In Argentina, the Departamento Protección del Patrimonio Cultural (DPPL) of the Federal Police is the primary agency responsible for the policing of heritage crime. The DPPL has three main methods through which they work. First, they focus on the active prevention and policing of heritage-related crimes, both national and international. There is a strong focus on combatting the illicit trafficking of cultural objects, specifically within the MERCOSUR network ${ }^{13}$. Second, the DPPL organises and participates in (inter-)national conferences and courses to disseminate knowledge concerning art crime policing to international, national, provincial, and municipal stakeholders. Third, the DPPL maintains the Programa de Protección de Patrimonio Cultural that collects information on missing and stolen cultural objects in a central database. Currently, this contains 5,500 cultural objects. This national registry is supported by Interpol and the Ministerio de Seguridad and Ministerio de Cultural of Argentina.

Argentina has a long history of policy concerning the protection of heritage objects. In 1913, the National Congress established legislation for the protection of cultural objects originating from Argentinian soil and stimulated scientific research into the protection of cultural heritage. In 1968, Argentinian civil law drastically changed with the implementation and modification of the discussion of cultural heritage as a public asset. Additional modification of the law saw the incorporation of archaeological and paleontological sites as having scientific interest, which moved these artefacts from the jurisdiction of the public domain to that of national or provincial jurisdiction. In 2003, by presidential decree, the Comité Argentino para Combatir el Tráfico Ilícito de Bienes Culturales was created within the Ministry of Culture. Currently, the Ministry of Culture's Secretaría de Patrimonio Cultural contains the Dirección Nacional de Bienes y Sitios Culturales. The main objectives of the Directorate are to develop and implement a national management system for cultural assets, safeguard tangible and intangible cultural herita-

\footnotetext{
13 Customs union between Argentina, Brazil, Paraguay, Uruguay, and Venezuela. Current associated states: Bolivia, Chile, Colombia, Ecuador, Guyana, Perú, and Surinam.
} 
ge, prevent and combat the illicit trafficking of cultural heritage, and protect land and underwater cultural heritage. The Directorate oversees the Comité Nacional de Lucha contra el Tráfico Ilícito de Bienes Culturales, a national committee combatting illicit trafficking of cultural property. This national committee is an inter-ministerial collegiate body that consists of various organisations concerned with the protection of cultural heritage.

\subsection{Belize}

When a crime is committed at, or against a heritage site in Belize, the Police inform the Institute of Archaeology (IA), or vice versa, depending on who received the initial report, and investigation of the crime proceeds with both bodies contributing. Crimes committed at publicly accessible heritage sites are most likely to fall under the jurisdiction of Belize's Tourism Police who maintain a presence at these locations. Infractions at other locations, such as remote jungle sites, may be assigned to another police unit depending on the circumstances. In most cases the IA serves as the investigation's technical team, providing information about the site and objects that have been subject to crime, and the police engage in the traditional criminal investigation aspects. The IA and Police are the two primary actors in heritage crime cases in Belize, with the country's Customs and Immigration departments playing a supporting role in investigations if they happened to seize cultural objects being trafficked.

The IA is a department of the National Institute of Culture and History (NICH), who are charged with the protection of cultural heritage. Part IV of the NICH Act, Chapter 331 (2000; Revised Edition 2003), where this mandate originates, defines protected art categories as ancient monuments and antiquities and further defines those as being articles, constructions, or natural features that have been worked by humans, and that are over 100 years old. The NICH Act furthermore states that no person may possess ancient monuments or antiquities unless they have a written license from the IA. Violation of this may result in a fine and a prison sentence of up to 5 years. People who come into possession of these objects have 15 days to register it with the IA, with the penalty for violation being a fine and up to 2 years in prison. People who find these specific objects have 14 days to report it and face a fine and a prison sentence of up to 5 years if they omit doing so. The $\mathrm{NICH}$ Act gives the IA the power to serve written notice on anyone they believe is in violation of the above, and to confiscate the object or monument in question on behalf of the state. The act makes clear that licenses issued by the IA to possess antiquities or ancient monuments are not transferable and that no person can "give, sell, transfer or otherwise part with the possession, custody or control of any ancient monument or antiquity" without consent in writing from the IA. The $\mathrm{NICH}$ Act further defines actions such as wilfully destroying ancient monuments and removing antiquities from ancient monuments as offences that carry fines and potential prison sentences.

Difficulties in policing of heritage crime stem largely from two practical issues. The first is that Belize is an archaeologically rich country, and remains of the Maya civilisation can be found nearly everywhere, from off the coast under territorial waters too deep within the jungle that blankets large portions of the country. It is impossible to maintain a police or IA presence at even the known heritage sites within the country as they number in the tens of thousands, and there are countless sites that are unknown to the IA, but may be known to those wishing to exploit heritage. Belize, having bilateral agreements to prevent the illicit trafficking of cultural objects with Guatemala and México, suffer a similar practical reality: borders running through deep jungle with both countries with discovered and undiscovered Maya civilisation remains lying along those borders. These borders are impossible to police, making interregional cooperation the only option for dealing with transnational flows of illicit material. Second, Belize is rapidly developing, and new areas are being opened for road building and agriculture. Such development is vital for the future of Belize, but can challenge the preservation mandate of the $\mathrm{NICH}$ Act. While penalties exist for heritage destruction in these circumstances, monitoring capabilities for all development projects are limited. Belize mitigates these issues with a strong focus on raising public awareness about the importance of preserving cultural heritage and the obligations that exist to report the discovery of, and crimes against ancient monuments and artefacts. Belize is a country of less than 400,000 inhabitants, meaning that it is possible to reach a sizeable proportion of citizens with awareness raising, outreach, and education campaigns. Eye-catching posters and flyers, public events, and inclusion of heritage 
protection in school curricula are all seen as having a strong societal effect against heritage crime.

\subsection{Brazil}

In Brazil, the Divisão de Repressão a Crimes contra o Meio Ambiente e Patrimônio Histórico (DELEMA$\mathrm{PH})$ of the Federal Police is tasked with the investigation of heritage crime. DELEMAPH has a central unit in Brasilia, and has representatives in each of Brazil's 27 states. Only those objects that are registered as bem tombado are under the jurisdiction of DELEMAPH. This registration, that can be provided by federal, state, and municipal administration, is protected via federal law by Decree $N^{\circ} 25$ that dates from 30 November 1937 and marks the first legal protection of Brazilian cultural heritage. The Decree defines cultural heritage as both movable and immovable property existing within Brazil that the conservation of which is of public interest, either due to its connection to important events in Brazilian history, or due to its exceptional archaeological, bibliographic, artistic or ethnographic value. Additionally, bem tombado also encompasses certain natural monuments, sites and landscapes that are considered important to conserve and protect. There is thus a clear distinction between those objects that are bem tombado, and those that are not. For example, if a contemporary painting is stolen that is not registered, the civil police investigates the case as a regular property theft.

The Instituto do Patrimônio Histórico e Artístico Nacional (IPHAN) is, amongst other tasks, responsible for the prevention of heritage crimes. The IPHAN maintains a database (Bens Culturais Arqueológicos ou tombados Procurados, BCP) of stolen and missing heritage objects. This database is maintained at federal level, and records archaeological or other bem tombado that are reported stolen or missing. The database only holds those objects that are appropriately registered, and that are reported to the database. The database is actively used by IPHAN to facilitate organisations such as police, customs agencies, and the Public Ministry with information necessary to retrieve the object. Within Decree $\mathrm{N}^{\circ} 25$, article 16 indicates a legal obligation to register all stolen or missing objects to IPHAN. In reality, not all objects are always registered. Whenever IPHAN receives a registration, they immediately contact the Ministry of Foreign Affairs, the Federal Police (DELEMAPH), and those dealers and art traders who are associated with CNART (Cadastro de Negociantes de Obras de Arte e Antiguidades), a nationwide dealer register containing approximately 2000 art dealers. Since the BCP does not register every single cultural object, there are other institutes who maintain databases, such as the List of Wanted Cultural Property by the Public Ministry of the State of Minas Gerais (Lista de Bens Culturais Procurados), the Register of Missing Museum Goods (Cadastro de Bens Musealizados Desaparecidos) from the Brazilian Museum Institute (Brasileiro de $\mathrm{Mu}-$ seus), and the List of Missing Works of the National Library (Lista de Obras Desaparecidas). These databases, together with the BCP, also share their records of stolen objects, via the NCB, to Interpol's Stolen Works of Art Database in Lyon.

The regular procedure in the case of heritage crime is for an owner to contact the police and report the object stolen, and for the police issue an incident report. With the incident report, the owner can notify IPHAN (when concerning bem tombado) who then records the missing object into the database. Then, CNART is contacted. If the object was taken from a museum or other institute, the Brazilian Museum Institute is also notified. Internationally Brazil is a member of Mercosur, El PAcCTO, and through a collaboration between Itau Bank and ICOM, Brazil has started working on a Brazilian Red List of Cultural Heritage.

\subsection{Chile}

The primary responsibility of protecting cultural objects in Chile lies with the Public Ministry. Chilean cultural objects may be identified as Monumentos Nacionales via the Council of National Monuments, and significant cultural objects that do not meet the classification of National Monument (such as sculptures, commemorative sites, state museum collections, and archaeological and paleontological artefacts of Chilean origin), are protected by criminal Law $\mathrm{N}^{\circ} 17.2883$ that states that all aforementioned objects are under the care and protection of the Chilean State. There is no specific legislation for other types of cultural objects, apart from a specific 'exit' law ( $\mathrm{N}^{\circ}$ 17.2364) that mandates that none of these objects may leave the country without an authorisation document issued by the National Museum of Fine Arts. Guaranteeing restrictions or returns of artworks that the museum considers to be of national heritage interest. The organisation that oversees this law 
is the Servicio Nacional de Aduanas. Whenever a crime against, or theft of, one of these cultural objects occurs, the Public Ministry is responsible for instructing the correct police authorities. Depending on the crime, the type of object, and the geographical range of the crime, these forces are either the Carabineros de Chile, a uniformed police force with a large presence throughout Chile, the Policía de Investigactiones (PDI) which encompasses the sub-division BIDEMA (Brigada de Delitos Medio Ambientales y Contral el Patrimonio Cultural), or, if concerning fraud, appropriation, or another economic related crime, the Brigadas Investigadoras de Delitos Económicos.

In 2002, BIDEMA was created as part of the PDI. The officers of BIDEMA are primarily tasked with the investigation of theft, damage, or involuntary seizure. In 2019, the Lucha contra el Tráfico Ilícito de Bienes Patrimoniales (TIBP) was created, which was a result of the cooperation of various governmental institutions, and has a bridging function between police and the relevant Ministries. In instances of heritage crime, they serve as a collaborative partner for the identification of the affected cultural objects, connecting heritage crime to the appropriate policing entity.

In heritage crime cases, the policing procedure is determined based on the type of crime committed. When it concerns the theft of a cultural object, BIDEMA is tasked with the case and subsequently opens a case with the Public Ministry. The organisation or individual who experienced the theft delivers a description and images of the stolen object and BIDEMA then adds the property to a national database that is structured via OBJECT-ID. The PDI disseminates the findings to the Interpol's National Central Bureau (NCB) of Chile who in turn sends the information to Interpol for inclusion in the Stolen Works of Art Database. The TIBP Unit is charged with informing the National Customs Agency who work with a Theft Alert which is immediately, nationally and internationally, implemented via the Latin American and Caribbean Theft Alert Network of REDLAD (La Red Latinoamericana y del Caribe para la Democracia). The TBIP regularly uses the media to raise public awareness in the hopes this will make the cultural object difficult to traffic or sell. When the crime concerns damage or destruction to a National Monument, first the Council of National Monuments or the National Heritage Service are informed and file complaints against the perpetrators, before the Public
Ministry steps in and instructs the police on the appropriate action to be taken.

Apart from its cooperation with the Theft Alert Network, Chile also collaborates within Mercosur Cultural - Tráfico Ilícito which is an interregional network that encourages cooperation in the MERCOSUR network, for example by sharing databases with information concerning cultural property in transit, authentication certificates, and evaluating best practices. Chile has bilateral agreements concerning the combatting of illicit trafficking of cultural property with México, Ecuador, and Perú. With Perú, Chile maintains extensive cooperation training customs agents in north Chile to prevent trafficking via the Atacama Desert.

\subsection{Colombia}

In Colombia, the Área Protección al Turismo y Patrimonio Cultural of the Unidades Básicas de Investigación Criminal is tasked with the protection of the national archaeological, cultural, and religious heritage. Besides the protection of cultural objects, the Directorate is also responsible for the environment, natural resources, and tourism. The Directorate is part of the national police force and provides support in criminal police investigations concerning heritage crimes, but also focuses on human trafficking, child and adolescent sexual exploitation, and the trafficking of flora and fauna. Additionally, they provide technical and forensic support for crime scenes in these fields.

When a heritage crime is committed, the police agency to which the crime is reported to, usually the national police, will inform the Attorney General of the State who assigns the investigation to the appropriate police unit. The strength of the Colombian Directorate is their strong uniformed presence at the main tourism and heritage sites throughout Colombia, resulting in, certain cases, the time between reporting and policing to be very short. Often institutes external to the Directorate are contacted during the investigation of a case, such as the Instituto Colombiano de Antropología e Historia (UBIC), Archivo General de la Nación, and the Servicio Geológico Colombiano. They are tasked with supporting the technical identification of artefacts, as well as providing expert opinions on authenticity. Additionally, through UBIC, an alert is made to the NCB of Interpol in Colombia, who in turn sends alerts to those 
states that are most likely to be linked to the heritage asset in some way, such as being a possible destination for a trafficked object. The countries most frequently cooperated with are all in South America (for example Ecuador, Perú, Bolivia, Panamá), but they also maintain strong ties with the United States, countries in Europe (Spain, Switzerland), and Asia (China, United Arab Emirates).

\subsection{Costa Rica}

In Costa Rica, the Organismo de Investigación Judicial functions as headquarters for five police departments. Within the Departamento the Investigaciones Criminales the Sección de Delitos Varios and its unit Patrimonio Arcquelógico y Cultural are tasked with the investigation of heritage crimes. Currently, the unit consists of three investigative police officers. The unit works closely together with the Department of Protection of Cultural Heritage of the National Museum of Costa Rica.

In the case of a heritage crime, the first mandatory procedure is to contact the National Museum of Costa Rica. The Department of Protection of Cultural Heritage of the museum is called upon for its expertise, particularly for determining the authenticity of the object, and to evaluate which specific elements of the object might indicate its destination in the market. Internationally, the Unit is allied with various regional and international police organisations. Costa Rica is a member of AMERIPOL, El PAcCTO, and reports to the NCB of Costa Rica who, if necessary, contacts Interpol for objects to be added to the Stolen Works of Art Database.

Although the Unit does not maintain a separate database for cultural objects, they actively record criminal data concerning heritage crimes. From 2013 to 2020, 67 criminal cases were reported in the different provinces of Costa Rica. Most cases were reported in the provinces San José and Guanacaste. Additionally, 55 people were charged with a violation of law $\mathrm{N}^{\circ} 11496-\mathrm{C}$ (Ley sobre Patrimonio Nacional Arqueológico). This law protects archaeological national heritage, an umbrella term, encompassing archaeological objects, tangible and intangible heritage (either ancient or contemporary), indigenous tangible or intangible heritage, human remains, and flora and fauna related to this heritage. Specifically, the law prohibits the trade and export of these objects by both private and state institutions. The only organization allowed export cultural objects is the National Museum, who requires authorization of the Comisión Arqueológica Nacional. From 2016 to 2019, there were 799 archaeological objects confiscated nationwide that were in the process of being trafficked.

\subsection{Guatemala}

Guatemala's Public Ministry contains the Fiscalía de Sección de Delitos contra el Patrimonio Cultural de la Nación (henceforth Fiscalía), which is charged with the investigation and prosecution of heritage crimes. This office is headquartered within the UNESCO World Heritage site of Antigua Guatemala, with a regional headquarters in the Petén department, which houses many of the country's major archaeological sites. This office is charged with protecting, conserving, and recovering cultural objects that have been subject to crime as defined by Guatemala's penal code and cultural heritage law.

The looting of archaeological material and the subsequent trafficking of that material to foreign markets are the primary heritage crimes Guatemala experiences. Responding to these issues, the Departmento de Prevención y Control de Trafico Illicito de Bienes Culturales located within the Ministry of Culture and Sport serves as a technical department with direct specialty in looting and illicit trafficking cases. At a national level, this department manages trafficking cases, facilitates cooperation across offices and policing agencies, provides training regarding the collection of evidence in these cases, and aids in the development of policies to reduce theft and trafficking of heritage items. They also promote the signing of inter-institutional agreements across Guatemala's government ministries (for example with the Public Ministry in 2013 and the Tax Administration in 2015) to aid in investigations related to illicit trafficking of art.

At an international level, the office is tasked with monitoring public art sales for potentially-stolen Guatemalan pieces, presenting formal claims to Guatemalan pieces abroad, and alerting relevant governments bodies abroad and NGOs to thefts, by example through reporting stolen pieces to Interpol's database. The office represents Guatemala in international meetings, including those related to the 1970 UNESCO Convention, and plays an important role in the development of bilateral 
and multilateral agreements related to the prevention of art trafficking.

There have been attempts to create a specialised policing unit focusing on heritage crimes in Guatemala, and for a period there were dedicated agents based in the Unidad de Robos y Atracos of the División Especializada en Investigación Criminal de la Policía Nacional Civil tasked with investigating heritage crime cases. However, they were eventually reassigned to non-heritage-related theft cases due to the incredible workload of that unit. Both the Fiscalía and the Departmento de Prevención y Control de Trafico Illicito de Bienes Culturales however, may make investigation requests to the police and the police are obliged to provide their support. Both offices also maintain a strong working relationship with Guatemala's Interpol NCB. There is an active training regime for Guatemalan police officers related to this topic, particularly within the police's División de Protección a la Naturaleza.

Considering different circumstances, individuals with information about heritage crimes file a complaint with either the police or the Public Ministry, and preferably directly with the Fiscalía. Depending on who receives the claims, questions about the case are directed to the Fiscalía. Subsequently, the Departamento de Registro de Bienes Culturales y Coloniales of the Dirección General del Patrimonio Cultural y Natural in the Ministry of Culture and Sport is consulted to see if the piece(s) in question have been previously registered. If so, an Object ID-based theft report is prepared. If not, and photographs are available, a technical report about the object is issued. The reporting individual or organisation is requested further information to prepare an Object ID-based theft report.

Within Guatemala, this report is disseminated to the Fiscalía of the Ministerio Público, the Interpol NCB (reporting to Interpol database), customs, the Ministerio de Relaciones Exteriores, ICCROM Guatemala, and Guatemala's UNESCO office. Details are also disseminated through several Facebook pages to raise awareness in the general public. Internationally, the Ministerio de Relaciones Exteriores is charged with transferring information about the crime in question to relevant partner countries. On a more informal level, officials within the Departmento de Prevención y Control de Trafico Illicito de Bienes Culturales and the Fiscalía share details of heritage crimes directly with officials and insti- tutions in countries such as Argentina, Chile, Colombia, Ecuador, Perú, Paraguay, Uruguay, Costa Rica, El Salvador, Honduras and Mexico when necessary.

Within Latin America, Guatemala has signed bilateral cultural property-related agreements with México, Perú, and Belize; and has further agreements with the USA and Egypt. They are signatories of the OAS Convención de la OEA sobre la Defensa del Patrimonio Arqueológico, Histórico y Artístico de las Naciones Americanas, the Convención Centroamérica para la Protección del Patrimonio Cultural, the Convención Centroamericana para la Restitución y el Retorno de Objetos, and the Convención Centroamérica para la Realización de Exposiciones de Objetos Archaeological, Historical and Artistic, some of which have resulted in mutual returns of stolen art objects.

\subsection{Honduras}

The issue of illicit transfer and looting of artefacts in Honduras first came to public attention in the mid-nineteenth century, when many objects were looted from sites such as the UNESCO World Heritage Site Copán. Faced with these issues, the first measure taken by the central government was to establish Agreement $\mathrm{N}^{\circ} .4$ (January 28, 1845) which prohibited for individuals from removing cultural objects from Copán and placed the site in the custody of local authorities. In 1900, Agreement N. 127 elaborated on the previous agreement by prohibiting the export of artefacts from Copán, as well as other archaeological sites in Honduras. Between 1927 and 1934, a series of agreements were issues concerning the safeguarding of Copán, which remains a site at particular risk for heritage crime.

July 1952 saw the establishment of the Instituto Hondureño de Antropología e Historia (IHAH) with the mission of carrying out the protection, conservation, investigations, and dissemination of Honduras' cultural heritage. In 1994, the Fiscal Especial para Grupos Étnicos y Patrimonio Cultural was created, which was attached to the Public Ministry. For the past 30 years, the Unidad de Registro y Control of the IHAH has kept an archive of all cultural objects stolen from museums, churches, and private collections. The information in this archive was gathered after the objects were reported as stolen to cultural institutes, police, government, and even through the media. 
Honduras has ratified various international conventions such as the 1954 Hague Convention, 1972 UNESCO convention, 1976 Convenciones sobre la Defensa del Patrimonio Arqueologico, historico y artistico de las naciones Americanas, 1992 Convencion Centroamericana para la restitución y el retorno de objetos arquelogicos, historicos y artisticos, and the 2003 Convention for the safeguarding of intangible cultural heritage. In Honduras' Penal Code, article 4 of the law for the protection of cultural heritage of the nation, via Decree 220-97 (1997), established that Honduran cultural heritage remains a permanent, inalienable, imprescriptible, and non-tradeable property of the country. The purchase and sale of cultural heritage is completely prohibited in Honduras. However, at the same time, article 5 of the same Decree, established that privately-owned cultural objects (such as collections of religious institutes, or those who gained possession of artefacts before the law was ratified) are prohibited from sale and commercialisation. However, they can be transferred to the IHAH for custodianship.

\subsection{Nicaragua}

The policing of heritage crime in Nicaragua consists of a three-way amalgam between the Dirección de Investigaciones Económicas (DIE-PN) of the National Police, the Instituto Nicaragüense de Cultura (INC) and the Dirección Nacional de Patrimonio Cultural (DNPC). In the case of cultural heritage crimes, the DIE-PN works in close collaboration with the Nicaraguan Institute of Culture, which is the main governmental body concerned with the protection, conservation, repatriation, and promotion of the Patrimonio Cultural de la Nación.

When crime is reported, the collaboration between the National Police and the INC will result in a cooperation, depending on the type of crime, with one of the directorates of the DNPC. The overarching Directorate for Cultural Heritage deals primarily with the technical coordination of crimes concerning the illicit trafficking of cultural objects and crimes against tangible cultural heritage. The DNPC maintains the Registro Nacional de Bienes Culturales y de la Creación Artística that registers all known artefacts that exist within Nicaraguan national territory with the purpose of registering its description, ownership, and state of conservation. Additionally, the DNPC is the main body for carrying out exit controls of cultural objects that are not declared Cultural Heritage of the Nation, by providing export certificates. The exit of assets that are declared Cultural Heritage of the Nation is prohibited, unless it concerns scientific study or loan-agreements for temporary exhibition.

Other Directorates the National Police and INC work with are the National Directorate of Archaeology, which controls permits for archaeological and paleontological investigations carried out at national level; the Rubén Darío National Library and General Archive of the Nation which is concerned with the protection of documentary heritage and provides assistance with crimes concerning these specific assets; and the National Museum Directorate that manages public and private museums and supports managers therein with the protection of cultural property within the museum. Overarching all these Directorates is the Legal Advice Department that supports the Directorates, as well as the DIE-PN and INC, especially with the coordination and collaboration with the Attorney General's Office who acts as the state's legal representative.

Heritage crime can be reported to the National Police, or directly to the INC. In the event of a crime reported directly to INC, they immediately communicate to one of the Directorates listed above to start on-site inspection. Additionally, the DIE-PN is informed and, if necessary, the Customs Agency. On-site technical inspection is done to determine the scope of the event and to inventory the cultural objects involved. A valuation of the damages to the site and artefacts is assessed and an authentication check is executed. This results in a technical report that is disseminated to all Directorates, the INC, and the DIE-PN, the Attorney General's Office and the Legal Advice Department. In the event that a heritage crime is directly reported to the DIE-PN, the police investigation procedure starts with notifying the INC who then executes the previous discussed steps providing expert documentation about the cultural assets.

Nicaragua is a signatory to various international decrees such as Aprobación de la Convención Sobre Defensa del Patrimonio Arqueológico, Histórico y Artístico de las Naciones Americanas (1976), and Aprobación de las Convenciones Centroamericanas para la Restitución y el Retorno de los Objetos Arqueológicos, Históricos y Artísticos; para la Realización de Exposiciones de Objetos Arqueológicos, Históricos y Artísti- 
cos; y para la Protección del Patrimonio Cultura (1998).

\subsection{Panamá}

The Dirección Nacional del Patrimonio Histórico (DNPH) of the Ministry of Culture oversees the country's national heritage. In the case of illicit trafficking, or damage to monuments, law $\mathrm{N}^{\circ} 14$ (1982, modified law $\left.\mathrm{N}^{\circ} 58,2003\right)$ provides the $\mathrm{DNPH}$ with the authority to carry out sanctions, such as fines. In 2015, the Penal Code was adapted, resulting in article 214, section 10, arguing that five to ten years in prison can be sanctioned in the case of theft of national historical heritage, as well as objects that hold scientific, religious, cultural, or artistic value. With this adaptation of the Penal Code, the investigation and protection of cultural objects became part of the Public Ministry's responsibility.

Heritage crimes are usually reported to the police or directly to the DNPH.

\subsection{Paraguay}

In Paraguay, there is no dedicated police force for heritage crime. However, by presidential Decree $\mathrm{N}^{\circ}$ 5.375 (2016), the Comisión Nacional de Prevención y Combate al Tráfico Ilícito de Bienes Culturales was created. The Committee is represented by members from the Secretaría Nacional de Cultura, the Ministries of Foreign Affairs and Interior, the National Police, Interpol, Customs Agency, Secretaría Nacional de Turismo, and the Public Ministry. In the case of a heritage crime such as theft, the Public Prosecutors Office informs the Committee who then reports the crime to Interpol for quick dissemination into its database. Additionally, the Committee notifies, via the National Police, the customs agencies of Argentina and Brazil.

Paraguay is a member and signatory of various international and regional collaborations. They are a member of MERCOSUR, specifically MERCOSUR Cultural, and the Comunidad de Estados Latinoamericanos y Caribeños (CELAC). Concerning CELAC, Paraguay was a signatory of the Declaration of Belén (2015) in which article 25 declared that all member states should 1) create a voluntary registry of material cultural assets, 2) use international networks to repatriate illegally stolen cultural property and 3) have the Cultural Ministers of CELAC countries establish a strategy for defining 'cultural assets'.

Paraguay's strengths regarding policing of heritage crime include the involvement and knowledge of the civil population and institutions concerning national heritage, the various training courses on the prevention of illicit trafficking and the combatting of online trafficking. However, the absence of a heritage crime unit and a lack of economic resources are considered areas for improvement.

\subsection{Perú}

Heritage crime in Perú can be classified as either administrative or criminal, based on the nature of the offence, and each follows a different reporting and investigative pathway.

Article 49 of the Ley General de Patrimonio Cultural (Ley $\left.N^{\circ} 28296,2007\right)$, which charges the Ministry of Culture with levying fines, as well as seizing or confiscating cultural objects that are considered to be Patrimonio Cultural de la Nación, defines a series of administrative heritage crimes. These crimes involving cultural objects include: not registering them with the ministry, damaging them, attempting to export them without a permit from the Instituto Nacional de Cultura, and illegal excavation.

Investigation of administrative crimes is undertaken by the Dirección de Control y Supervisión of the Dirección General de Defensa del Patrimonio Cultural (DGDPC) of the Ministry of Culture, which is based in Lima. If a case involves the illicit trafficking of cultural objects, or the investigation of artefacts that have left Perú without proper authorization, the Dirección de Recuperaciones, also within the DGDPC of the Ministry of Culture, play a prominent role. These directorates investigate and produce a technical report that provides the details of the heritage crime and includes how the offender was identified. Following the production of this report, the DGDPC imposes the correct penalty on the offender (fine and/or confiscation) under the law. Beyond Lima, these penalties are, in theory, imposed by the Direcciones Desconcentradas de Cultura of each region, but in practice only the Cuzco region maintains a specific body to impose heritage crime sanctions, and the DGDPC in Lima imposes heritage crime penalties for the rest of the country. 
Heritage crimes that are classified as criminal in Perú are defined by the Penal Code (1991). Articles 186 and 189 of the Penal Code specifically note that theft or robbery of "the cultural heritage of the Nation" is to be considered aggravated under the law, thus carrying significantly increased custodial sentences. Articles 226 through 231 define a series of criminal offences against, specifically, pre-Hispanic cultural objects (as well as other cultural objects that have been defined as bienes culturales) all of which carry significant custodial sentences. These crimes include knowingly excavating, removing, or destroying pre-Hispanic cultural objects from heritage sites, illegally exporting or commercializing pre-Hispanic cultural objects, and corruption on the part of public officials during the commission of any of these other crimes.

To investigate criminal cases as defined above, Peru maintains the Unidad de Delitos contra el Patrimonio Cultural within the Dirección de Policía Fiscal. This unit of about 5 officers has jurisdiction over criminal heritage crime cases throughout the entire country, however in practice most of their work is office-based and conducted in Lima, where the support cases that are being actively investigated by a public prosecutor. In that vein, the Public prosecutor's office maintains expertise in heritage crimes. Currently there is one senior prosecutor and two deputy prosecutors who are present during inspections of crimes at heritage sites and who are in charge of maintaining heritage crime case files and gathering evidence, however much of the actual investigation of the particulars or these crimes is undertaken by experts within the Ministry of Culture. If the Public Prosecutor believes there is basis for criminal proceedings, the case goes to court. It is worth noting, again, that while the Unidad de Delitos contra el Patrimonio Cultural has jurisdiction over heritage crimes in the whole country, there are no regional offices or heritage crime subunits, and thus no specialized police or prosecutor presence beyond Lima. In Cuzco, heritage crimes cases are often managed by the police working with the Tourism Public Prosecutor. Beyond, police units with regional jurisdiction and prosecutors on duty manage heritage crime cases.

\section{Conclusion}

As evidenced by this state-by-state survey, different Latin American countries apply different strategies to the policing of heritage crime. Those strategies are largely governed by three factors: the scope and scale of heritage crime within the country; the administrative structure of the country's governmental institutions and policing agencies; and the legal framework that defines heritage crime and mandates protection. While some similarities exist across various Latin American states regarding these three factors, our survey illustrates the need for a context-specific understanding of heritage crime policing on a state-by-state basis.

For example, Argentina, Brazil and Chile have established police units dedicated to cultural heritage crimes within the federal police, and either maintain their own database (Argentina, Chile) or a register of cultural assets stolen or missing from various institutes (Brazil). Countries such as Costa Rica, Nicaragua, and Colombia have dedicated police officers within police units that are not solely concerned with cultural heritage, but also with, for example, tourism, environmental crimes, property theft, or economic crimes. Additionally, other countries rely primarily on Ministerial expertise in conjunction with normal police investigations, as there is no police unit dedicated to heritage crimes (Paraguay, Honduras).

Representatives from many of the countries contacted for this survey cited that a lack of specialised personnel and high workloads were relative weaknesses in their efforts to protect cultural objects from crime. Overall, a lack of economic resources for development in policing in this area, despite a general sense that protection of heritage objects is of national interest, was considered the primary barrier to improved policing of heritage crime among several respondents. This response parallels the findings of a 2019 study in which representatives within comparable ministries and agencies within Europe cited lack of funding and funding-related staffing issues as a significant barrier to effective heritage crime prevention ${ }^{14}$. Although many of the countries in this

14 Brodie, Neil; Yates, Donna; Slot, Brigitte; Batura, Olga; van Wanrooij, Niels; op 't Hoog, Gabrielle. Illicit Trade in Cultural Goods in Europe: Characteristics, criminal justice responses and an analysis of the applicability of technologies in the combat against the trade. Report. Directorate-General for Education, Youth, Sport and Culture. Brussels: European Commission, 2019. Available at: https://op.europa.eu/ 
survey have a completely different economic reality than those within Europe, it is notable that money is an issue in both locations. The financial commitment to heritage crime policing is a clear area where further research is needed.

Overall, there is increased cooperation in the region, and in cases of theft of cultural objects, Interpol is a partner for all countries discussed in the survey. The different coordination efforts in Latin America, such as El PACcTo, AMERIPOL, and MERCOSUR (Cultural), show increasing efforts of the states to combat the illicit trafficking of cultural heritage, and to establish both formal and informal communication lines between countries. There is an important factor here for the national law enforcement agencies of Latin American countries, as these regional collaborations are between law enforcement agencies, and not via cultural institutions. Therefore, police agencies are often the first line of defence when crimes against heritage occur. Having a limited line, or absent, first line of defence can result in increased crime against heritage. The exact form that these regional cooperation efforts take in heritage crime cases and analysis of their effectiveness, then, is another clear area to direct further research.

This article is a first step to widen the discourse of heritage crime policing focusing specifically on policing strategies in Latin America. Through this survey, we aimed to provide an overview of various police practices within this crime 'niche' and to shed a light on police cooperation in the region. We also consider this to be a call to action for more research to be conducted on heritage crime policing generally, and Latin America specifically. Although in Latin America, the political backing of the policing of heritage crime is greater than, for example, in Europe ${ }^{15}$, further research into police cooperation in Latin America, and national police practices 'on the ground' can uncover the daily routines and decision-making processes of those tasked with protecting cultural heritage. In that way, we can have a more detailed knowledge of how individual police practitioners shape the policing of heritage crimes.

en/publication-detail/-/publication/d79a105a-a6aa-11e9-9d0101aa75ed71a1. Accessed on: March 2, 2021.

15 BLOCK, Ludo. European police cooperation on art crime: Comparative overview. Journal of Art Crime, v. 5, n. 1, p. 13-26. 2011.

\section{Acknowledgements}

We would like to thank the respondents who took the time to carefully respond to our questions during this project. We would also like to thank Diana Berzina for her support in producing this paper and Camila Malig Jedlicki for her assistance with translating. This project has received funding from the European Research Council (ERC) under the European Union's Horizon 2020 research and innovation programme (grant agreement $\left.n^{\circ} 804851\right)$.

\section{References}

BLOCK, Ludo. European police cooperation on art crime: Comparative overview. Journal of Art Crime, v. 5, n. 1, p. 13-26. 2011.

Agencia EFE. Bolivia recovers stolen art thanks to help from U.S. couple. April 9, 2015. Available at: https://www. efe.com/efe/english/life/bolivia-recovers-stolen-artthanks-to-help-from-u-s-couple/50000263-2582190. Accessed on: March 2, 2021.

Brodie, Neil; Sabrine, Isber. The illegal excavation and trade of Syrian cultural objects: a view from the ground. Journal of Field Archaeology, v. 43, n. 1, p. 74-84. 2018

Brodie, Neil; Yates, Donna; Slot, Brigitte; Batura, Olga; van Wanrooij, Niels; op 't Hoog, Gabrielle. Illicit Trade in Cultural Goods in Europe: Characteristics, criminal justice responses and an analysis of the applicability of technologies in the combat against the trade. Report. Directorate-General for Education, Youth, Sport and Culture. Brussels: European Commission, 2019. Available at: https://op.europa. $\mathrm{eu} / \mathrm{en} /$ publication-detail/-/publication/d79a105aa6aa-11e9-9d01-01aa75ed71a1. Accessed on: March 2, 2021.

CLARÍN. Los detienen en un control de rutina cuando querían contrabandear obras de arte hacia Uruguay. September 7, 2015. Available at: https://www.clarin. $\mathrm{com} /$ policiales/gualeguaychu-caen-querian-contrabandear-uruguay_0_r1otP7tP7e.html. Accessed on: March 2, 2021.

Coggins, Clemency. Illicit traffic of pre-Columbian antiquities. Art Journal, v. 29, Autumn, p. 94-114. 1969. 
Coggins, Clemency. New legislation to control the international traffic in antiquities. Archaeology, v. 29, n. 1, p. 14-15. 1976.

Coggins, Clemency. United states cultural property legislation: Observations of a combatant. International Journal of Cultural Property, v. 7, n. 1, p. 52-68. 1998.

El PACcTO. New cooperation tools to investigate trafficking in cultural property [press release]. June 23, 2020. Available at: https://www.elpaccto.eu/en/news/new-cooperation-tools-to-investigate-trafficking-in-cultural-property/. Accessed on: March 2, 2021.

Europol. 101 arrested and 19,000 stolen artefacts recovered in international crackdown on art trafficking [press release]. May 6, 2020. Available at: https:/ / www.europol.europa. $\mathrm{eu} /$ newsroom/news/101-arrested-and-19000-stolenartefacts-recovered-in-international-crackdown-arttrafficking. Accessed on: March 2, 2021.

Gilgan, Elizabeth. Looting and the market for Maya objects: A Belizean perspective. In: Brodie, Neil; Doole, Jennifer; Renfrew, Colin (Eds.). Trade in illicit antiquities: The destruction of the world's archaeological heritage. Cambridge: McDonald Institute, 2001. p. 425-442.

Gutchen, Mark. The destruction of archaeological resources in Belize, Central America. Journal of Field Archaeology, v. 10, p. 217-227. 1983.

Hardy, Samuel Andrew. Illicit trafficking, provenance research and due diligence: The state of the art. Paris: United Nations Educational, Scientific and Cultural Organization (UNESCO), 2016.

Kerr, John. The securitization and policing of art theft: The case of London. London: Routledge, 2016.

Mackenzie, Simon; Brodie, Neil; Yates, Donna. Traffcking Culture: New Directions in Researching the Global Market in Illicit Antiquities. New York: Routledge, 2020.

Mackenzie, Simon; Davis, Tess. Temple looting in Cambodia. Anatomy of a statue trafficking network. British Journal of Criminology, v. 54, n. 5, p. 722-740. 2014.

Manacorda, Stefano; Chappell, Duncan. (Eds.). Crime in the art and antiquities world: Illegal trafficking in cultural property. New York: Springer Science \& Business Media, 2011.

Oosterman, Naomi. Regional overviews of the policing of art crime in the European Union. In: Hufnagel, Saskia; Chappell, Duncan. (Eds.). The Palgrave Handbook on Art Crime. London: Palgrave Macmillan, 2019.
Paredes Maury, Sofia. Surviving in the rain forest: The realities of looting in the rural villages of El Petén, Guatemala. FAMSI Reports, 1999. Available at: http://www.famsi. org/reports/95096/95096ParedesMaury01.pdf. Accessed on: March 21, 2016.

Polk, Kenneth; Chappell, Duncan. Policing and prosecution of heritage crime: revisiting the Cordata-just how organised is the international traffic in cultural heritage?. In: Mitsilegas, Valsamis; Hufnagel, Saskia; Moiseienko, Anton. (Eds.). Research Handbook on Transnational Crime. London: Edward Elgar Publishing, 2019.

Robertson, Marle Green. Monument thievery in Mesoamerica. American Antiquity, v. 37, n. 2, p. 147-155. 1972.

Rodríguez Temiño, Ignacio; Roma ValdÉs, Antonio. Fighting against the archaeological looting and the illicit trade of antiquities in Spain. International Journal of Cultural Property, v. 22, n. 1, p. 111-130. 2015.

Yates, Donna. Displacement, Deforestation, and Drugs: Antiquities Trafficking and the Narcotics Support Economies of Guatemala. In: Kila, Joris; Balcells, Marc. (Eds.). Cultural Property Crime. An overview and analysis contemporary perspectives and trends. Leiden: Brill, 2014. p. 21-36.

Yates, Donna. Church theft, insecurity, and community justice: The reality of source-end regulation of the market for illicit Bolivian cultural objects. European Journal on Criminal Policy and Research, v. 20, n. 4, p. 445-457. 2014.

Yates, Donna. Illicit cultural property from Latin America: Looting, trafficking, and sale. In: Desmarais, France. (Ed.). Countering illicit traffic in cultural goods: The global challenge of protecting the world's heritage. Paris: ICOM, 2015. p. 33-46.

Yates, Donna. Reality and practicality: Challenges to effective cultural property policy on the ground in Latin America. International Journal of Cultural Property, v. 22, n. 2-3, p. 337-356. 2015.

Yates, Donna. The global traffic in looted cultural objects. In Rafter, Nicole; Carrabine, Eamonn. (Eds.). The Oxford Encyclopedia of Crime, Media, and Popular Culture. Oxford: Oxford University Press, 2016.

Yates, Donna. Cultural heritage offences in Latin America: Textile traffickers, mummy mailers, silver smugglers, and virgin vandals. In: Hufnagel, Saskia; Chappell, Duncan. (Eds.). The Palgrave Handbook on Art Crime. London: Routledge, 2019. p. 483-501. 
Yates, Donna; Mackenzie, Simon; Smith, Emiline. The Yates, Donna; Tremain, Cara Grace. (Eds.). The Market cultural capitalists: Notes on the ongoing reconfigura- for Mesoamerica: Reflections on the Sale of Pre-Columbian Antion of trafficking culture in Asia. Crime, Media, Cultu- tiquities. Gainsville: University Press of Florida, 2019. re, v. 13, n. 2, p. 245-254. 2017. 
Para publicar na Revista de Direito Internacional, acesse o endereço eletrônico www.rdi.uniceub.br ou www.brazilianjournal.org.

Observe as normas de publicação, para facilitar e agilizar o trabalho de edição. 